\title{
Contents IMIA Yearbook of Medical Informatics 2007
}

From the sponsor

President's Statement

Editorial

Keynote
E.R. Reinhardt

Workflow Solutions with Healthcare IT

N. Lorenzi

Towards IMIA 2015 — the IMIA Strategic Plan

A. Geissbuhler, R. Haux, C. A. Kulikowski

Biomedical Informatics for Sustainable Health Systems

J.-C. Healy

Biomedical Informatics for Sustainable Health Systems

Special Section: Biomedical Informatics for Sustainable Health Systems

Survey

E. Coiera, E. J. S. Hovenga

Building a Sustainable Health System

Synopsis C. Lovis

Sustainable Health Care Systems

Best paper selection Content summaries of*:

Anderson GF, Frogner BK, Johns RA, Reinhardt UE. Health care spending and use of information technology in OECD countries. Health Aff 2006 May-Jun;25(3):819-31

Bagayoko CO, Muller H, Geissbuhler A. Assessment of Internet-based tele-medicine in Africa (the RAFT project). Comput Med Imaging Graph 2006 Sep-0ct;30(6-7):407-16

Croll PR, Croll J. Investigating risk exposure in e-health systems. Int J Med Inform 2006 Nov 22

Shabo A. A global socio-economic-medico-legal model for the sustainability of longitudinal electronic health records. Part 1. Methods Inf Med 2006;45(3):240-5

Shabo A. A global socio-economic-medico-legal model for the sustainability of longitudinal electronic health records. Part 2. Methods Inf Med 2006;45(5):498-505

Section 1: Health and Clinical Management

Survey J. S. Einbinder, D. W. Bates

Leveraging Information Technology to Improve Quality and Safety

Synopsis J. Bergmann

Health and Clinical Management - Impact on Clinical Outcome

Best paper selection

Content summaries of*:

Feldman PH, Murtaugh CM, Pezzin LE, McDonald MV, Peng TR. Just-in-time evidence-based e-mail "reminders" in home health care: impact on patient outcomes. Health Serv Res 2005 Jun;40(3):865-85. Han YY, Carcillo JA, Venkataraman ST, Clark RS, Watson RS, Nguyen TC, Bayir H, Orr RA. Unexpected increased mortality after implementation of a commercially sold computerized physician order entry system. Pediatrics 2005 Dec; 116(6):1506-12

Pizziferri L, Kittler AF, Volk LA, Honour MM, Gupta S, Wang S, Wang T, Lippincott M, Li Q, Bates DW. Primary care physician time utilization before and after implementation of an electronic health record: a time-motion study. J Biomed Inform 2005 Jun;38(3):176-88

* The complete papers can be accessed in the Yearbook's full electronic version, provided that permission has been granted by the copyright holder(s) 
Section 2: Patient Records

\author{
Survey \\ P. Knaup, O. Bott, C. Kohl, C. Lovis, S. Garde \\ Electronic Patient Records: Moving from Islands and Bridges towards Electronic Health Records \\ for Continuity of Care \\ Synopsis S. Meystre \\ Electronic Patient Records: Some Answers to the Data Representation and Reuse Challenges \\ Best paper selection \\ Content summaries of*: \\ Ferranti JM, Musser RC, Kawamoto K, Hammond WE. The clinical document architecture and the \\ continuity of care record: a critical analysis. J Am Med Inform Assoc 2006 May-Jun; 13(3):245-52 \\ Los RK, van Ginneken AM, van der Lei J. OpenSDE: a strategy for expressive and flexible \\ structured data entry. Int J Med Inform 2005 Jul;74(6):481-90 \\ Melton GB, Hripcsak G. Automated detection of adverse events using natural language processing of \\ discharge summaries. J Am Med Inform Assoc 2005 Jul-Aug;12(4):448-57 \\ Pakhomov SV, Coden A, Chute CG. Developing a corpus of clinical notes manually annotated for \\ part-of-speech. Int J Med Inform 2006 Jun;75(6):418-29
}

Section 3: Health Information Systems

Survey S. Sfakianakis, C. E. Chronaki, F. Chiarugi, F. Confort, D. G. Katehakis

Reflections on the Role of Open Source in Health Information System Interoperability

Synopsis $\quad 0$. J. Bott

Health Information Systems - Technology and Acceptance

Best paper selection Content summaries of*:

Despont-Gros C, Landau R, Rutschmann 0, Simon J, Lovis C. The digital pen and paper. Evaluation and acceptance of a new data acquisition device in clinical settings. Methods Inf Med 2005;44(3):359-68

Ghinea G, Asgari S, Moradi A, Serif T. A Jini-based solution for electronic prescriptions. IEEE Trans Inf Technol Biomed 2006 0ct;10(4):794-802

Liu CT, Yang PT, Yeh YT, Wang BL. The impacts of smart cards on hospital information systems — an investigation of the first phase of the national health insurance smart card project in Taiwan. Int J Med Inform. 2006 Feb;75(2): 173-81

Maglaveras N, Chouvarda I, Koutkias VG, Gogou G, Lekka I, Goulis D, et al. The Citizen Health System (CHS): a modular medical contact center providing quality telemedicine services. IEEE Trans Inf Technol Biomed 2005 Sep;9(3):353-62

de Toledo P, Jimenez S, del Pozo F, Roca J, Alonso A, Hernandez C. Telemedicine experience for chronic care in COPD. IEEE Trans Inf Technol Biomed 2006 Jul;10(3):567-73

* The complete papers can be accessed in the Yearbook's full electronic version, provided that permission has been granted by the copyright holder(s) 
Section 4: Sensor, Signal and Imaging Informatics

Survey D. Konstantas

An Overview of Wearable and Implantable Medical Sensors

\section{Synopsis R. Westphal}

Sensors, Medical Image and Signal Processing

Best paper selection Content summaries of*:

DiMaio SP, Salcudean SE. Needle steering and motion planning in soft tissues. IEEE Trans Biomed Eng 2005 Jun;52(6):965-74

Istrate D, Castelli E, Vacher M, Besacier L, Serignat JF. Information extraction from sound for medical telemonitoring. IEEE Trans Inf Technol Biomed 2006 Apr; 10(2):264-74

Kim HK, Biggs SJ, Schloerb DW, Carmena JM, Lebedev MA, Nicolelis MA, et al. Continuous shared control for stabilizing reaching and grasping with brain-machine interfaces. IEEE Trans Biomed Eng 2006 Jun;53(6): 1164-73

Moore Jackson MM, Mason SG, Birch GE. Analyzing trends in brain interface technology: a method to compare studies. Ann Biomed Eng 2006 May;34(5):859-78

Parkka J, Ermes M, Korpipaa P, Mantyjarvi J, Peltola J, Korhonen I. Activity classification using realistic data from wearable sensors. IEEE Trans Inf Technol Biomed 2006 Jan; 10(1):119-28

Section 5: Decision Support, Knowledge Representation and Management

Survey T. Y. Leong, K. Kaiser, S. Miksch Free and Open Source Enabling Technologies for Patient-Centric, Guideline-Based Clinical Decision Support: A Survey

\section{Synopsis B. Brigl}

Decision Support, Knowledge Representation and Management: A Balancing Act between Clinical Use and Implementation of Sophisticated Reasoning Techniques?

\section{Best paper selection Content summaries of*:}

Bellazzi R, Larizza C, Magni P, Bellazzi R. Temporal data mining for the quality assessment of hemodialysis services. Artif Intell Med 2005 May;34(1):25-39

Maviglia SM, Yoon CS, Bates DW, Kuperman G. Knowledgelink: impact of context-sensitive information retrieval on clinicians' information needs. J Am Med Inform Assoc 2006 Jan-Feb;13(1):67-73

McGregor JC, Weekes E, Forrest GN, Standiford HC, Perencevich EN, Furuno JP, et al. Impact of a computerized clinical decision support system on reducing inappropriate antimicrobial use: a randomized controlled trial. J Am Med Inform Assoc 2006 Jul-Aug; 13(4):378-84

Rubin DL, Dameron O, Bashir Y, Grossman D, Dev P, Musen MA. Using ontologies linked with geometric models to reason about penetrating injuries. Artif Intell Med 2006 Jul;37(3):167-76

* The complete papers can be accessed in the Yearbook's full electronic version, provided that permission has been granted by the copyright holder(s) 
VIII

(C) 2007

IMIA and Schattauer GmbH

Section 6: Education and Consumer Informatics

Survey J. Mantas

Education and Consumer Health Informatics

Synopsis M. Marschollek

Advances in Education and Consumer Health Informatics

Best paper selection Content summaries of*:

Baker L, Rideout J, Gertler P, Raube K. Effect of an Internet-based system for doctor-patient communication on health care spending. J Am Med Inform Assoc 2005 Sep-0ct;12(5):530-6

Gaudinat A, Ruch P, Joubert M, Uziel P, Strauss A, Thonnet M, et al. Health search engine with e-document analysis for reliable search results. Int J Med Inform 2006 Jan;75(1):73-85

van den Brink JL, Moorman PW, de Boer MF, Pruyn JF, Verwoerd CD, van Bemmel JH. Involving the patient: a prospective study on use, appreciation and effectiveness of an information system in head and neck cancer care. Int J Med Inform 2005 0ct;74(10):839-49

Woo CW, Evens MW, Freedman R, Glass M, Shim LS, Zhang Y, et al. An intelligent tutoring system that generates a natural language dialogue using dynamic multi-level planning. Artif Intell Med 2006 Sep;38(1):25-46

Section 7: Bioinformatics

Survey L. J. Frey, V. Maojo, J. Mitchell

Bioinformatics Linkage of Heterogeneous Clinical and Genomic Information in Support of Personalized Medicine

Synopsis E. Lang

Integrating Bioinformatics into Clinical Practice: Progress and Evaluation

\section{Best paper selection Content summaries of*:}

Cai Z, Mao X, Li S, Wei L. Genome comparison using Gene Ontology (GO) with statistical testing. BMC Bioinformatics 2006 Aug 11;7:374

Choi JK, Yu U, Yoo 0J, Kim S. Differential coexpression analysis using microarray data and its application to human cancer. Bioinformatics 2005 Dec 15;21(24):4348-55

Goh CS, Gianoulis TA, Liu Y, Li J, Paccanaro A, Lussier YA, et al. Integration of curated databases to identify genotype-phenotype associations. BMC Genomics 2006 0ct 12;7:257

Mansmann U. Genomic profiling. Interplay between clinical epidemiology, bioinformatics and biostatistics. Methods Inf Med.2005;44(3):454-60

Reviews M.-C. Beuscart-Zéphir, P. Elkin, S. Pelayo, R. Beuscart

The Human Factors Engineering Approach to Biomedical Informatics Projects: State of the Art, Results, Benefits and Challenges

A. Ozdas, R. Miller, L.R. Waitman

Care Provider Order Entry (CPOE): A perspective on factors leading to success or to failure

* The complete papers can be accessed in the Yearbook's full electronic version, provided that permission has been granted by the copyright holder(s) 
Research \& Education

M. Bennani Othmani, S. Diouny, K. Balar

Medical Informatics in Morocco: Casablanca Medical Informatics Laboratory

E. Coiera, F. Magrabi, V. Sintchenko, T. Zrimec, G. McDonnell, G. Chung, G. Tsafnat

The Centre for Health Informatics at the University of New South Wales - a clinical informatics

research centre

D. J. Severtson, L. Pape, P. Flatley Brennan, G. N. Phillips, Jr.

Biomedical Informatics Training at the University of Wisconsin-Madison

H. Tanaka, J. Nakaya

Research and education for Biomedical Informatics at Tokyo Medical and Dental University

History of Medical Informatics

Editorial

N. Lorenzi

40 Years of IMIA: Shaping Medical Informatics Worldwide

S. Kaihara

International Medical Informatics Association (IMIA): 1986-1989

M. Ball

Moving Forward, Looking Back ... Reminiscences

J. van Bemmel

Tempus Fugit

C. Kulikowski

IMIA: Coalescing Medical Informatics Worldwide for 40 Years

S. Huesing

IMIA - A 40 year Organizational overview

H. Peterson, M. Hutter

IMIA's Publication History

Information on IMIA

Information on IMIA

Honorary Fellows

National and Corresponding Members

Institutional Members

Addresses of IMIA Member Societies

Information on IMIA Working Groups and Special Interest Groups

Information on IMIA Regions

Information on APAMI (Asia Pacific Association for Medical Informatics)

Information on Helina (African Region)

Information on IMIA-LAC (Federation of Health Societies in Latin America)

Information on North-American Medical Informatics (NAMI)

Information on EFMI (European Federation For Medical Informatics)

Information on EFMI Working Groups 